Journal of

Molecular Microbiology

and Biotechnology

\title{
Role of CcpA in Polyhydroxybutyrate Biosynthesis in a Newly Isolated Bacillus sp. MA3.3
}

\author{
M.S.L. Lopes ${ }^{a} \quad$ N. Steinert ${ }^{b} \quad$ J.D. Rojas ${ }^{a} \quad$ W. Hillen ${ }^{b} \quad$ J.G.C. Gomez ${ }^{a} \quad$ L.F. Silva ${ }^{a}$ \\ a Departamento de Microbiologia, Instituto de Ciências Biomédicas, Universidade de São Paulo, São Paulo, Brazil; \\ ${ }^{b}$ Lehrstuhl für Mikrobiologie, Abteilung für Biologie, Biochemie und Genetik, Friedrich-Alexander-Universität \\ Erlangen-Nürnberg, Erlangen, Germany
}

\section{Key Words}

CcpA $\cdot$ Polyhydroxybutyrate $\cdot$ Catabolite repression •

Nitrogen metabolism $\cdot$ Xylose $\cdot$ Bacillus

\begin{abstract}
The ссpA gene was inactivated in the polyhydroxybutyrate (PHB)-producing strain Bacillus sp. MA3.3 in order to reduce glucose catabolite repression over pentoses and develop improved bacterial strains for the production of PHB from lignocellulosic hydrolysates. Mutant Bacillus sp. MSL7 $\triangle C \mathrm{CpA}$ are unable to grow on glucose and ammonia as sole carbon and nitrogen sources, respectively. Supplementation of glutamate as the nitrogen source or the substitution of the carbon source by xylose allowed the mutant to partially recover its growth performance. RT-PCR showed that CcpA stimulates the expression of the operon ( $g / t A B)$, responsible for ammonia assimilation via glutamate in Bacillus sp. MA3.3. Moreover, it was demonstrated that the supplementation of xylose or glutamate was capable of stimulating glt $A B$ operon expression independently of CcpA. In PHB production experiments in mineral media, it has been observed that the glucose catabolite repression over the pentoses was partially released in MSL7. Although the carbohydrate consumption is faster in the cсpA mutant, the biomass and PHB bio-
\end{abstract}

synthesis are lower, even with supplementation of glutamate. This is attributed to an increase of acetyl-CoA flux towards the tricarboxylic acid cycle observed in the mutant.

Copyright $\odot 2011$ S. Karger AG, Basel

\section{Introduction}

Polyhydroxybutyrate (PHB) is produced by many bacteria and archaea in response to various environmental conditions. The accumulation of PHB increases in some bacteria when growth is limited by a nutrient other than carbon, such as nitrogen [McCool and Cannon, 2001]. PHB structural properties are similar to those of polypropylene, with the advantage of being biodegradable, biocompatible and produced from renewable carbon sources [Harding et al., 2007].

Gram-negative bacteria, such as Escherichia coli, contain outer membrane lipopolysaccharide endotoxins, which may contaminate PHB during the extraction process and may induce undesirable immunogenic reactions [Chen and $\mathrm{Wu}, 2005$; Lee et al., 1995]. For that reason,

W. Hillen has since passed away.

\section{KARGER}

Fax +41613061234 E-Mail karger@karger.ch www.karger.com
(C) 2011 S. Karger AG, Basel

$1464-1801 / 11 / 0202-0063 \$ 38.00 / 0$

Accessible online at:

www.karger.com $/ \mathrm{mmb}$
L.F. Silva

Departamento de Microbiologia, Instituto de Ciências Biomédicas

Universidade de São Paulo. Av. Prof. Lineus Prestes, 1374

Cidade Universitária, São Paulo, SP 05509-000 (Brazil)

Tel. +55 113091 7730,E-Mail lukneif@icb.usp.br 
Gram-positive microorganisms are more suitable to produce PHB for medical applications [Valappil et al., 2008]. In a previous screening for PHB-producing bacteria using inexpensive substrates, a mangrove soil-isolated $\mathrm{Ba}$ cillus sp. MA3.3, closely related to $B$. megaterium, was isolated and reached promising results on PHB accumulation [Lopes et al., 2009]. However, when it grows in sugars usually found in lignocellulosic hydrolysates, glucose exerts a strong catabolite repression over xylose and arabinose.

In Gram-positive bacteria, the metabolism of different carbon sources is coordinated by CcpA. Glucose metabolism activates CcpA that binds to catabolite-responsive elements ( $\mathrm{cre}$ ) which usually overlap promoters of catabolite-repressed genes. For example, the xylose catabolism $x y l A B E$ operon in B. megaterium has three cre sites that can respond to different signals in different intensities [Gösseringer et al., 1997]. However, CcpA mediates both repression and activation of genes. Among the genes repressed by CcpA are those encoding enzymes required for the utilization of secondary carbon sources, as well as genes of the tricarboxylic acid (TCA) cycle. The genes activated by CcpA include those required for overflow metabolism, glycolysis and the biosynthesis of certain amino acids [Fujita, 2009].

A Bacillus sp. MSL7 $\triangle \mathrm{CcpA}$, carrying a ccpA chromosomal deletion, was constructed to reduce glucose catabolite repression over pentoses, thus allowing the improvement of PHB production from lignocellulosic hydrolysates.

\section{Results and Discussion}

\section{Construction and Characterization of the CcpA}

Mutant

Using primers $\mathrm{P} 2 \mathrm{C}$ and $\mathrm{P} 4 \mathrm{C}$, we characterized the gene ccpA of Bacillus sp. MA3.3 and its flanking region (fig. 1, lane 2). Those regions showed high similarity with the orthologous regions of $B$. subtilis 168 (online suppl. table 1 , www.karger.com/doi/10.1159/000324502). Sprehe et al. [2007] investigated the carbon catabolite repression in $B$. subtilis 168 and constructed pWH338 to obtain a chromosomal deletion of $c c p A$ by substituting $\operatorname{ccp} A$ with the kanamycin resistance gene $a p h A 3$. Due to the high similarity found between MA3.3 and B. subtilis 168 , the previous construction made by Sprehe et al. [2007] was used to delete $c c p A$ in Bacillus sp. MA3.3. After protoplast transformation of Bacillus sp. MA3.3 with pWH338, the kanamycin-resistant Bacillus sp. MSL7 $\Delta$ CcpA was selected. Using

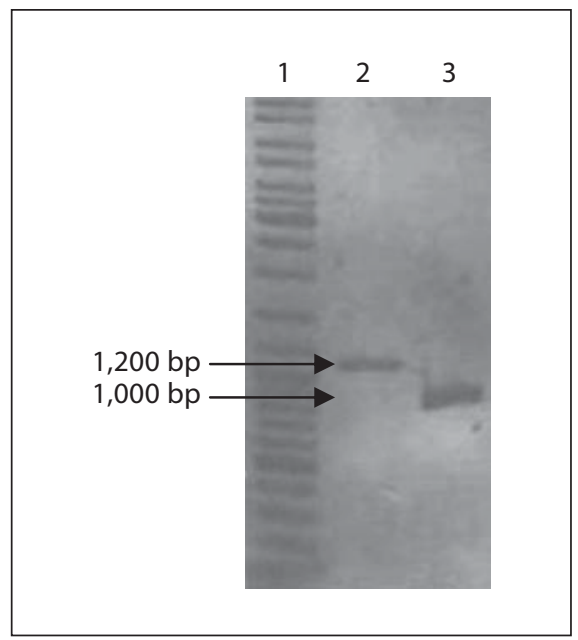

Fig. 1. PCR analysis of gene substitution in Bacillus sp. MSL7 $(\triangle \mathrm{CcpA})$. The gene $c c p A$ of $B$. megaterium MA3.3 was amplified using primers $\mathrm{P} 2 \mathrm{C}$ and $\mathrm{P} 4 \mathrm{C}(1,200 \mathrm{bp}$; lane 2$)$. The same primers were used to confirm that $c c p A$ was substituted by the kanamycin resistance gene aphA3 (1,000 bp; lane 3). 100-bp peqGOLD reference marker (Peqlab; lane 1).

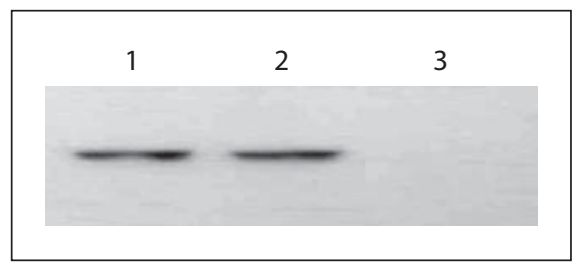

Fig. 2. Western blot analysis with specific anti-CcpA antibodies Bacillus sp. MSL7 $\triangle$ CcpA. SDS-PAGE gel was loaded with the same concentration of crude protein extract of Bacillus sp. MA3.3 (lane 2) and Bacillus sp. MSL7 (lane 3), and subjected to Western blot with anti-CcpA. Purified CcpA was used as a control (lane 1).

the aforementioned primers, $\mathrm{P} 2 \mathrm{C}$ and $\mathrm{P} 4 \mathrm{C}$, the PCR analysis of MSL7 demonstrated that ccpA was substituted by the kanamycin resistance gene aphA3 (fig. 1, lane 3). The gene substitution resulted in a shorter DNA amplicon in comparison to the wild-type amplicon (fig. 1).

We analyzed the CcpA synthesis in the wild-type $B a$ cillus sp. MA3.3 and in the recombinant MSL7 $\triangle$ CcpA by Western blot assays with specific anti-CcpA antibodies. The translation of CcpA in Bacillus sp. MA3.3 was confirmed (fig. 2, lane 2), while no translation product was detected in the recombinant strain (fig. 2, lane 3). A purified CcpA from B. subtilis 168 was used as the experiment control (fig. 2, lane 1). Therefore, both PCR and Western 


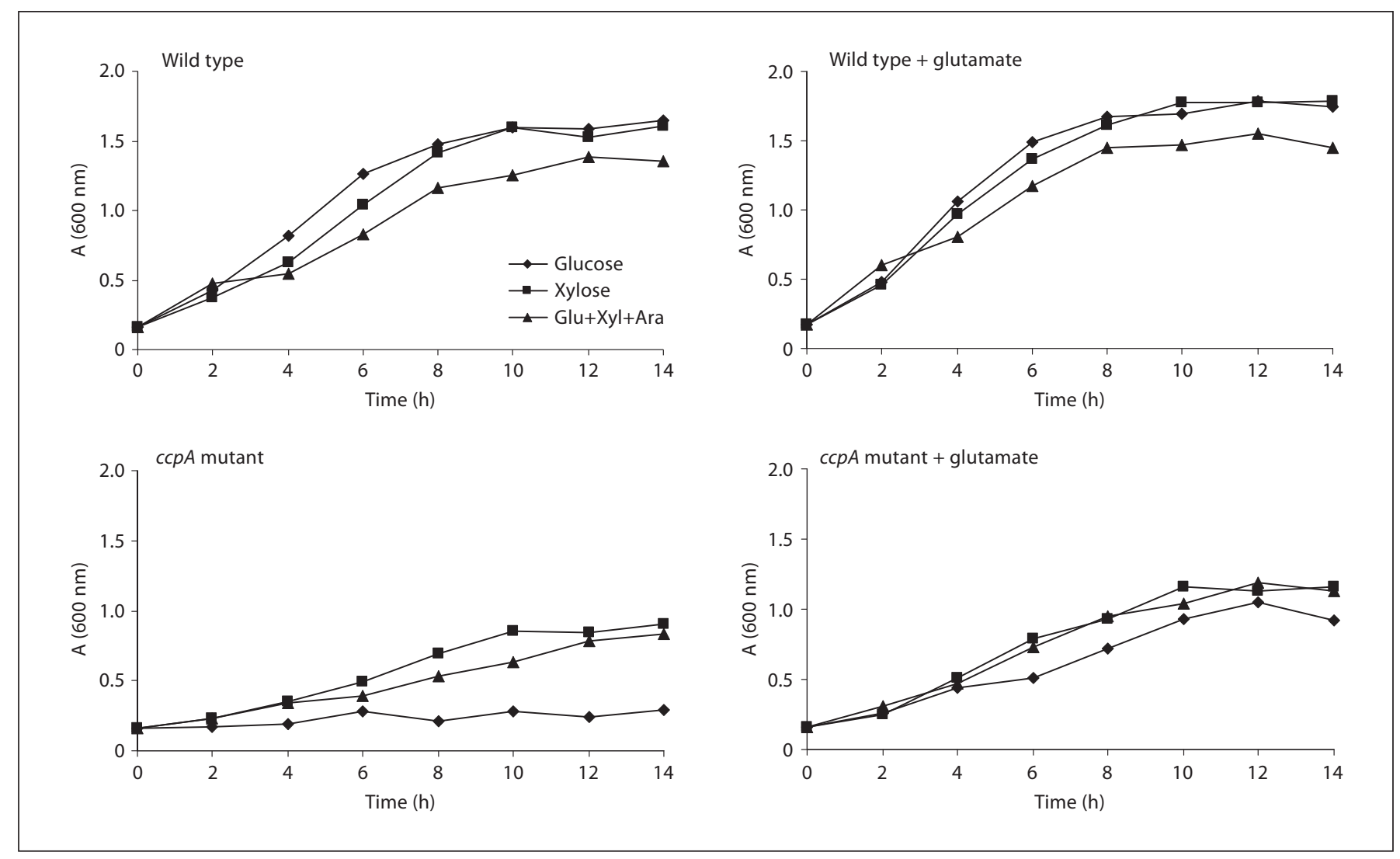

Fig. 3. Growth experiments with Bacillus sp. MA3.3 and Bacillus sp. MSL7 $\Delta$ CcpA in M9 medium or M9 supplemented with glutamate.

blot analysis confirmed the deletion of ccpA in Bacillus sp. MSL7 ( $\triangle \mathrm{CcpA})$.

\section{Growth Experiments of Bacillus sp. MSL7 $\triangle C c p A$}

To evaluate the growth capability of the mutant Bacillus sp. MSL7 $\triangle \mathrm{CcpA}$, experiments were performed with M9 supplemented with carbohydrates (fig. 3). The mutant was unable to grow on glucose and presented reduced growth on xylose or mixtures of carbohydrates. Moreover, the supplementation of glutamate allowed the mutant to partially recover its growth performance.

The involvement of CcpA on glutamate biosynthesis in B. subtilis has been described previously [Belitsky et al., 2000; Faires et al., 1999; Wacker et al., 2003]. Ammonia is assimilated via glutamate, which is exclusively synthesized by the glutamine synthetase and glutamate synthase (encoded by the gltAB operon). Glutamine synthetase catalyses the formation of glutamine from glutamate and ammonium, and glutamate synthase converts 2-oxoglutarate and glutamine to two molecules of glutamate.
One of these molecules of glutamate can be recycled to glutamine, while the second molecule is now available for anabolism [Belitsky et al., 2000; Faires et al., 1999]. CcpA is needed to induce the glt $A B$ operon when supplemented with glucose and ammonium as a carbon and nitrogen source, respectively [Belitsky et al., 2000; Faires et al., 1999; Wacker et al., 2003].

RT-PCR was used to investigate how CcpA controls the expression of gltAB operon in the Bacillus sp. MA3.3 and its recombinant. Analyses were performed using the RNA extraction of a culture of the wild-type strain in M9 supplemented with glucose and xylose (fig. 4, lanes 2 and 3 , respectively), RNA from Bacillus sp. MSL7 $\Delta$ CcpA cultivated in M9 with glucose and xylose (fig. 4, lanes 4 and 5, respectively), and, finally, RNA from Bacillus sp. MSL7 $\Delta$ CcpA cultivated in M9 supplemented with glutamate and glucose and xylose (fig. 4, lanes 6 and 7, respectively). As described previously for $B$. subtilis, the $c c p A$ mutant was incapable of inducing a gltAB operon when supplemented with glucose and ammonium as the carbon and 
Table 1. PHB production by Bacillus sp. MA3.3 and Bacillus sp. MSL7 in mineral minimal medium supplemented with glucose (G); xylose $(\mathrm{X})$; glucose and xylose $(\mathrm{G}+\mathrm{X})$; and glucose, xylose and arabinose $(\mathrm{G}+\mathrm{X}+\mathrm{A})$

\begin{tabular}{|c|c|c|c|c|c|c|c|c|}
\hline \multirow[t]{2}{*}{ Sugar } & \multicolumn{4}{|c|}{ MA3.3 (wild type) } & \multicolumn{4}{|c|}{ MSL7 ( $\Delta$ CcpA mutant) } \\
\hline & $\mathrm{CDW}, \mathrm{g} \cdot 1^{-1}$ & $X_{R}, g \cdot 1^{-1}$ & $\mathrm{X}_{\mathrm{PHB}}, \mathrm{g} \cdot \mathrm{l}^{-1}$ & $\%$ PHB & CDW, $g \cdot 1^{-1}$ & $X_{R}, g \cdot l^{-1}$ & $X_{\mathrm{PHB}}, \mathrm{g} \cdot \mathrm{l}^{-1}$ & $\%$ PHB \\
\hline \multicolumn{9}{|c|}{ Mineral media } \\
\hline G & $5.76 \pm 0.35$ & 2.18 & 3.58 & $62.15 \pm 2.23$ & $0.73 \pm 0.23$ & 0.73 & 0.00 & $0.00 \pm 0$ \\
\hline $\mathrm{X}$ & $5.23 \pm 0.29$ & 2.02 & 3.21 & $61.36 \pm 1.78$ & $2.05 \pm 0.43$ & 1.60 & 0.45 & $21.84 \pm 1.15$ \\
\hline $\mathrm{G}+\mathrm{X}$ & $3.86 \pm 0.34$ & 2.38 & 1.47 & $38.16 \pm 3.12$ & $2.24 \pm 0.18$ & 1.62 & 0.62 & $27.82 \pm 4.26$ \\
\hline $\mathrm{G}+\mathrm{X}+\mathrm{A}$ & $3.99 \pm 0.42$ & 2.40 & 1.59 & $39.89 \pm 2.76$ & $1.92 \pm 0.45$ & 1.45 & 0.47 & $24.32 \pm 2.12$ \\
\hline \multicolumn{9}{|c|}{ Mineral media supplemented with glutamate } \\
\hline G & $6.33 \pm 0.21$ & 2.50 & 3.83 & $60.43 \pm 2.23$ & $2.65 \pm 0.42$ & 1.77 & 0.88 & $33.27 \pm 2.01$ \\
\hline $\mathrm{X}$ & $5.54 \pm 0.18$ & 2.15 & 3.39 & $64.25 \pm 1.92$ & $3.16 \pm 0.52$ & 1.51 & 1.65 & $52.18 \pm 1.21$ \\
\hline $\mathrm{G}+\mathrm{X}$ & $4.23 \pm 0.31$ & 2.51 & 1.72 & $37.52 \pm 3.14$ & $3.64 \pm 0.12$ & 1.09 & 1.09 & $44.69 \pm 2.12$ \\
\hline $\mathrm{G}+\mathrm{X}+\mathrm{A}$ & $4.25 \pm 0.29$ & 2.51 & 1.74 & $40.74 \pm 2.63$ & $3.61 \pm 0.21$ & 1.18 & 1.18 & $45.27 \pm 2.78$ \\
\hline
\end{tabular}

Cell dry weight $(\mathrm{CDW})$, residual biomass $\left(\mathrm{X}_{\mathrm{R}}\right)$, $\mathrm{PHB}$ concentration $\left(\mathrm{X}_{\mathrm{PHB}}\right)$, and $\mathrm{PHB}$ content from cell dry weight $(\% \mathrm{PHB})$ are presented.

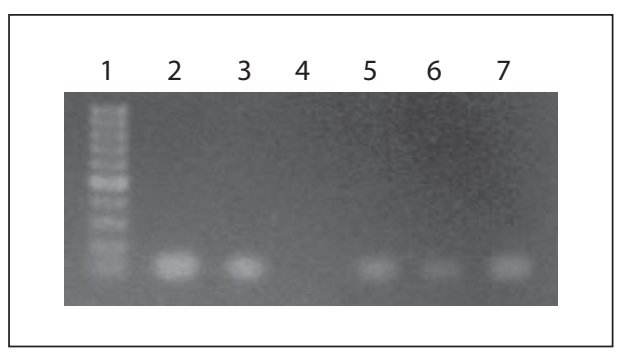

Fig. 4. RT-PCR of $g l t B$ (107 bp) expression in Bacillus sp. MA3 wild type and Bacillus sp. MSL7 ( $\Delta$ CcpA) cultivated in M9. Lane 1: 100 bp DNA ladder. Lanes 2 and 3: wild-type strain cultivated in glucose and xylose, respectively. Lanes 4 and 5: $\Delta \mathrm{CcpA}$ mutant cultivated in glucose and xylose, respectively. Lanes 6 and 7: M9 was supplemented with glutamate and the $\Delta \mathrm{CcpA}$ mutant was cultivated in glucose and xylose, respectively.

nitrogen source, respectively (fig. 4, lane 4). However, the substitution of the carbon source by xylose promotes glt $A B$ expression and growth independently of CcpA (fig. 4, lane 5). Similar results were verified by Wacker et al. [2003] in experiments with B. subtilis with glycerol and glucitol. While glucose and fructose were unable to induce the expression of glt $A B$ when CcpA was absent, glycerol and glucitol induced glt $A B$ expression. Thus, it is another example of non-PTS carbon sources inducing the expression of the glt $A B$ operon and allowing growth even in $c c p A$ mutants.

In a further analysis of ammonia consumption in the presence of glutamate, it was confirmed that glutamate not only stimulates the expression of gltAB (fig. 4, lane 6), but also promotes ammonia uptake in mineral medium containing glucose, probably by triggering the consumption of carbohydrates (fig. 5). Therefore, the data presented here show that glutamate could promote glt $A B$ expression allowing the utilization of glucose by $c c p A$ mutants of Bacillus sp. MA3.3. However, the mechanism of gltAB induction by CcpA is still not clear. Wacker et al. [2003] proposed that CcpA promotes the glycolysis overflow and subsequently glt $A B$ induction.

\section{PHB Production Experiments}

PHB production experiments with mineral media with higher sugar concentrations $\left(15 \mathrm{~g} \cdot \mathrm{l}^{-1}\right)$ were performed to observe the impact of $c c p A$ deletion on growth and PHB biosynthesis (table 1). The total cell dry weight is expressed separately in two parameters: biomass formation $\left(\mathrm{X}_{\mathrm{R}}\right)$ and $\mathrm{PHB}$ production $\left(\mathrm{X}_{\mathrm{PHB}}\right)$.

In experiments with ammonium as the only nitrogen source, the mutant presented lower values of cell dry weight and $\mathrm{PHB}$ content (\%PHB) in comparison with the wild type. In experiments using mineral media supplemented with glutamate, the wild type reached higher values of total biomass. As observed in growth experiments, glutamate allowed the $c c p A$ mutant cells to partially overcome the growth defect, especially in glucose. As demonstrated by the growth experiments, glutamate can stimulate carbohydrate and ammonia assimilation.

The glucose catabolite repression over the pentoses was partially released in MSL7 (fig. 5). Even though the 


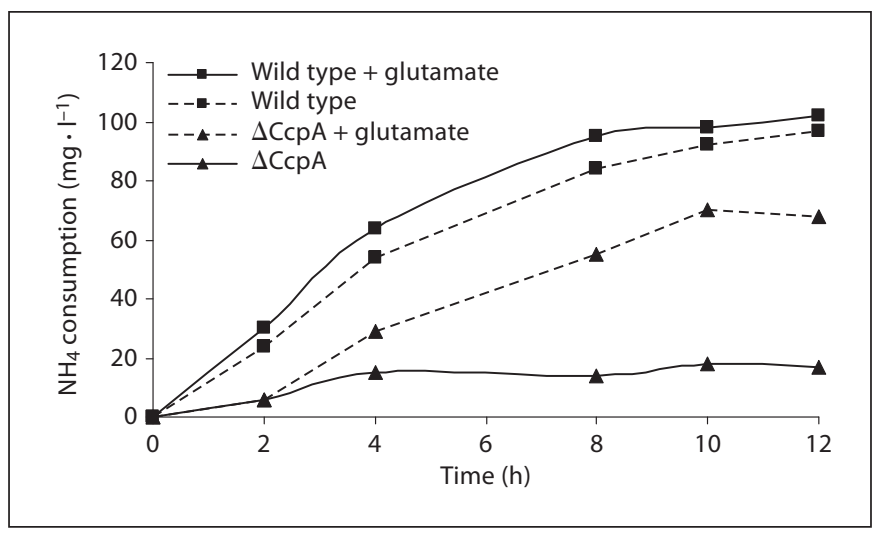

Fig. 5. Ammonia consumption of Bacillus sp. MA3.3 wild type and Bacillus sp. MSL7 ( $\Delta \mathrm{CcpA})$ in M9 medium supplemented with glucose $(\boldsymbol{\Delta})$ or M9 supplemented with glucose and glutamate (ם).

carbohydrate consumption is faster in the $\operatorname{ccp} A$ mutant, the biomass and PHB biosynthesis are lower. Therefore, the next question leads to the flux changes in central carbon metabolism in the mutant cell.

In the PHB biosynthetic pathway of Ralstonia eutropha, two molecules of acetyl coenzyme A (acetyl-CoA) are condensed by $\beta$-ketothiolase (PhaA), followed by a stereo-specific reduction catalyzed by an acetoacetyl$\mathrm{CoA}$ reductase $(\mathrm{PhaB})$ to produce the monomer $R$-(3)hydroxybutyryl-CoA, which is polymerized by PHA synthase (PhaC). These three pha genes are encoded by the phaCAB operon. In B. megaterium, the phaA gene is not located in the same operon, and other genes associated to PHB synthesis are clustered with phaC $[\mathrm{McCool}$ and Cannon, 1999]. PHB synthesis is regulated at the enzymatic level by the intracellular concentration of acetylCoA and free CoASH [Haywood et al., 1988; Lee et al., 1995]. Therefore, citrate synthase is an important control point based on the availability of CoASH [Henderson and Jones, 1997], which regulates the activity of 3-ketothiolase [Park and Lee, 1996].

In B. subtilis, CcpA directly represses the operon citZ$i c d-m d h$. This operon is formed by the genes citZ (citrate synthase), icd (isocitrate dehydrogenase) and $m d h$ (malate dehydrogenase) encoding the first enzymes of the TCA cycle [Kim et al., 2002; Lulko et al., 2007; Sonenshein, 2007]. To evaluate if the deletion of CcpA caused the higher flux of acetyl-CoA, measurements of $\mathrm{CO}_{2}$ production were performed during the $\mathrm{PHB}$ production experiments. MSL7 produced $0.23 \pm 0.01 \mathrm{~g}$ of $\mathrm{CO}_{2}$ per

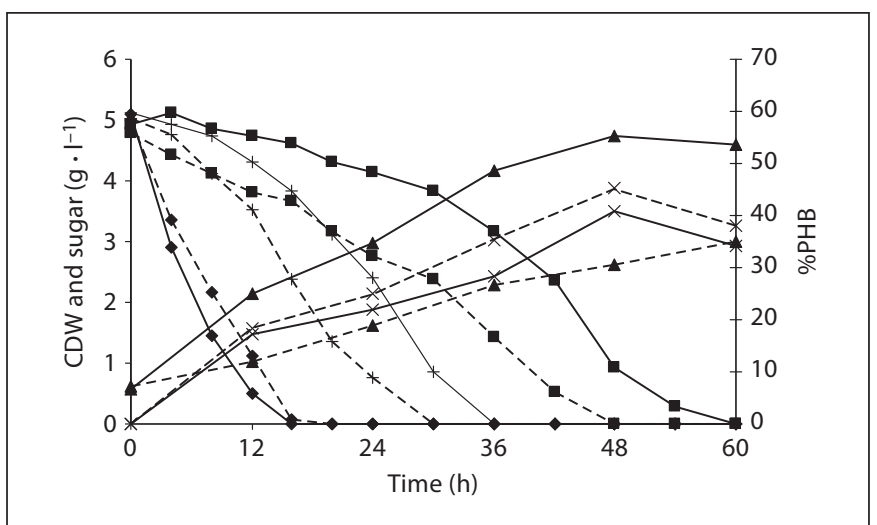

Fig. 6. PHB production by Bacillus sp. MA3.3 (solid line) and Bacillus sp. MSL7 (dashed line) in mineral media supplemented with glutamate and sugar mixtures: glucose $(\boldsymbol{\nabla})$, arabinose $(+)$, xylose (ם), cell dry weight (CDW; $\mathbf{\Delta})$, PHB content from cell dry weight (\% PHB; $\times)$.

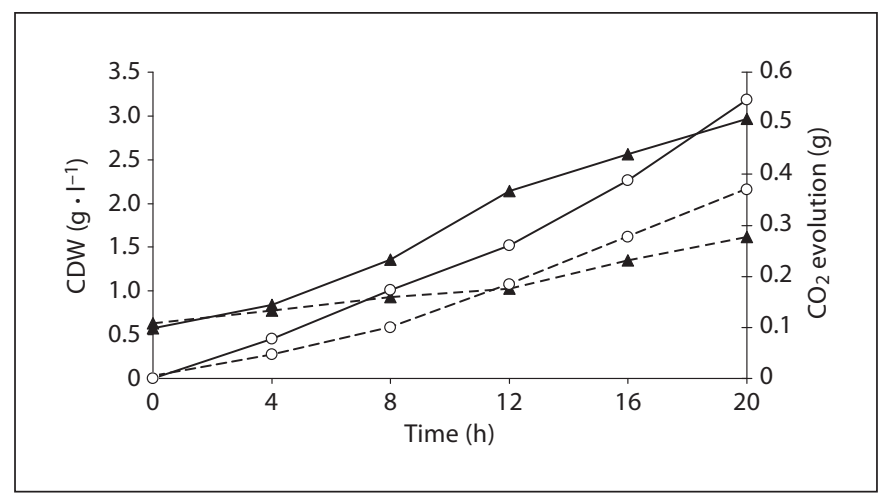

Fig. 7. $\mathrm{CO}_{2}$ evolution in by MA3.3 (solid line) and MSL7 (dashed line) in mineral media supplemented with glutamate and sugar mixtures: cell dry weight (CDW; $\mathbf{\Delta}$ ), and $\mathrm{CO}_{2}$ production $(\mathrm{O})$. The average from at least two independent experiments for each test, with the standard deviation lower than 0.03 for $\mathrm{CO}_{2}$ evolution.

gram of biomass, about $30 \%$ more than the wild type which produced $0.18 \pm 0.01 \mathrm{~g} \cdot \mathrm{l}^{-1}$. The increase on $\mathrm{CO}_{2}$ production rate in MSL7 indicates a higher flux through the TCA cycle, which could explain the lower biomass and PHB biosynthesis observed in the ccpA mutant. Those results suggest that a similar regulation mechanism of PHB biosynthesis observed in B. subtilis is presented in Bacillus sp. MA3.3, based on the control of citZ$i c d-m d h$ by CcpA. Additionally, the higher flux through the TCA cycle also results in a higher concentration of 
free CoASH, also considered inhibitory to PHB biosynthesis [Henderson and Jones, 1997].

Even in mineral media supplemented with glutamate, the $\operatorname{ccp} A$ mutant growth was lower than the wild-type growth (table 1). The literature suggests that this can be solved with the addition of methionine and branchedchain amino acids to the growth medium. The biosynthesis of those compounds also depends on a functional CcpA in B. subtilis [Ludwig et al., 2002]. On the other hand, the addition of a complex nitrogen source may make the medium more expensive, hampering the advantages of using inexpensive lignocellulosic hydrolysates.

In conclusion, the $c c p A$ mutant of Bacillus sp. MA3.3 showed a reduction of catabolite repression and, consequently, consumed sugar mixtures faster than the wild type. However, deregulation of genes necessary for the growth on mineral minimal media, including those required for ammonia consumption, was also observed. Moreover, since CcpA plays an important role in coordinating the carbon central metabolism in Bacillus sp. MA3.3, its deletion caused a higher flux to the TCA cycle, resulting in lower yields of biomass and PHB.

The efficient utilization of lignocellulosic hydrolysates relies on different cellular phenotypes. High PHB productivity depends on a strain with reduced catabolite repression and resistance to the inhibitor compounds present in the hydrolysate. In contrast, a high PHB yield is dependent on the fluxes of the central carbon metabolism. Recently, a procedure to improve complex phenotypes was described, one which is based on random mutagenesis of global regulators, inducing global pertubations of the transcriptome, and selection of phenotypic improvements [Alper and Stephanopoulos, 2007]. Therefore, instead of knocking out $c c p A$ as is described here, $\operatorname{ccpA}$ could be subjected to random mutagenesis and further selection of the desired cellular phenotype.

\section{Experimental Procedures}

\section{Bacterial Strains and Growth Conditions}

Bacillus sp. MSL7 $\triangle \mathrm{CcpA}\left(\operatorname{Kan}^{\mathrm{r}}\right)$ is a derivative of the soil-isolated Bacillus sp. MA3.3 [Lopes et al., 2009], and both were cultivated in nutrient broth at $30^{\circ} \mathrm{C}$ and $200 \mathrm{rev} \cdot \mathrm{min}^{-1}$. M9 medium [Sambrook et al., 1989] containing single sugar $\left(2 \mathrm{~g} \cdot \mathrm{l}^{-1}\right)$ or sugar mixtures $\left(1 \mathrm{~g} \cdot \mathrm{l}^{-1}\right.$ of each) was used in growth experiments. Mineral minimal medium [Rocha et al., 2008] supplemented with glucose $\left(15 \mathrm{~g} \cdot \mathrm{l}^{-1}\right)$; xylose $\left(15 \mathrm{~g} \cdot \mathrm{l}^{-1}\right)$; glucose and xylose $\left(7.5 \mathrm{~g} \cdot \mathrm{l}^{-1}\right.$ of each); or glucose, xylose and arabinose $\left(5 \mathrm{~g} \cdot \mathrm{l}^{-1}\right.$ of each) was used for the PHB production experiments. For further experiments, M9 and mineral media were supplemented with sodium glutamate $\left(2 \mathrm{~g} \cdot \mathrm{l}^{-1}\right)$.
Construction and Characterization of the CcpA Mutant

The gene $\operatorname{csp} A$ and its flanking region of Bacillus sp. MA3.3 were amplified using primers P2C: $5^{\prime}$-TACGTAAATACAAGAAATGA-3' and P4C: $5^{\prime}$-CCG TGTCTGAACTTTGG-3' (1 min of denaturation at $95^{\circ} \mathrm{C}, 1 \mathrm{~min}$ of annealing at $59^{\circ} \mathrm{C}$, and $3 \mathrm{~min}$ of extension at $72^{\circ} \mathrm{C}$ for a total of 30 cycles.). This sequence was compared with the orthologous region of B. subtilis 168 using the software DIALIGN [Morgenstern et al., 1996]. Protoplast transformation of Bacillus sp. MA3.3 [Rygus and Hillen, 1992] with pWH338 [Sprehe et al., 2007] was performed. In pWH338, the ccpA gene of $B$. subtilis 168 was substituted by the kanamycin resistance gene aphA3 [Sprehe et al., 2007]. For that reason, pWH338 was used to promote $c c p A$ deletion by homologous recombination in Bacillus sp. MA3.3. After protoplast regeneration, the cells were plated on M9 minimal medium containing glucose $(0.2 \%)$ and kanamycin $(80 \mathrm{mg} / \mathrm{l})$. The confirmation of $c c p A$ deletion was carried out by PCR analysis of the CcpA region and Western blot immunodetection using anti-CcpA rabbit antibodies as described previously [Küster et al., 1996; Sambrook et al., 1989].

\section{Reverse Transcription PCR}

Total RNA extraction was performed using Trizol (Gibco) and DNase treatment (Promega) as described by the manufacturers. RNA integrity was tested by electrophoresis in agarose gels using the phosphate buffer method [Farrel, 2005]. RNA quantification was performed by measuring absorbance at $260 \mathrm{~nm}$ using NanoDrop 1000 (Thermo Scientific). RNA samples were subjected to PCR with primers for the operon encoding for 16S rRNA to detect possible contamination with genomic DNA. cDNA was always synthesized with $5 \mu \mathrm{g}$ of RNA sample and the SuperScript ${ }^{\mathrm{TM}}$ III First-Strand Synthesis SuperMix kit (Invitrogen) with random hexamers. cDNA was used as a template for PCR using specific primers for glutamate synthase, gltB (5'-acggtttggtgtcaaaagcca and $5^{\prime}$-accttgttgccaggaagctg). The PCR program was conducted using a denaturation step of $3 \mathrm{~min}$ at $94^{\circ} \mathrm{C}$, followed by 30 cycles of $94^{\circ} \mathrm{C}$ for $30 \mathrm{~s}, 56^{\circ} \mathrm{C}$ for $30 \mathrm{~s}$ and $72^{\circ} \mathrm{C}$ for $2 \mathrm{~min}$, with a final extension step at $72^{\circ} \mathrm{C}$ for $10 \mathrm{~min}$.

\section{Analytical Methods}

Bacterial growth was evaluated spectrophotometrically $\left(\mathrm{OD}_{600} \mathrm{~nm}\right)$. Cell dry weight was determined gravimetrically as described by Silva et al. [2004], carbohydrates were determined by HPLC [Silva et al., 2004], and PHB amount was determined by gas chromatography of hydroxyalkanoate esters [Gomez et al., 1996]. $\mathrm{CO}_{2}$ was entrapped using barium hydroxide $(0.025 \mathrm{~N})$ and quantified by titration with $\mathrm{HCl}(0.05 \mathrm{M})$ using phenolphthalein $(0.04 \%)$ as a $\mathrm{pH}$ indicator. The following equation was used to calculate the $\mathrm{CO}_{2}$ evolution of the culture: $\mathrm{CO}_{2}(\mathrm{mg})=($ Volume $\mathrm{HCl}^{1}-$ Volume $\mathrm{HCl}^{2}$ ), with Volume $\mathrm{HCl}^{1}$ representing the volume of $\mathrm{HCl}$ used in the sample and Volume $\mathrm{HCl}^{2}$ representing the volume used in the blank reaction.

\section{Acknowledgements}

The study was supported by Fundação de Amparo à Pesquisa do Estado de São Paulo (FAPESP) and the Deutscher Akademischer Austausch Dienst (DAAD). We thank Maria Nikolakakou for her help with some of the experiments. 


\section{References}

Alper H, Stephanopoulos G: Global transcription machinery engineering: a new approach for improving cellular phenotype. Metab Eng 2007;9:258-267.

Belitsky BR, Wray LV, Fisher SH, Bohannon DE, Sonenshein AL: Role of TnrA in nitrogen source-dependent repression of Bacillus subtilis glutamate synthase gene expression. J Bacteriol 2000;182:5939-5947.

Chen GQ, Wu Q: The application of polyhydroxyalkanoates as tissue engineering materials. Biomaterials 2005;26:6565-6578.

Faires N, Tobisch S, Bachem S, Martin-Verstraete I, Hecker M, Stülke J: The catabolite control protein CcpA controls ammonium assimilation in Bacillus subtilis. J Mol Microbiol Biotechnol 1999;1:141-148.

Farrel RE Jr: RNA Methodologies: A Laboratory Guide for Isolation and Characterization. Amsterdam, Elsevier Academic Press, 2005.

Fujita Y: Carbon catabolite control of the metabolic network in Bacillus subtilis. Biosci Biotechnol Biochem 2009;73:245-259.

Gomez JGC, Rodrigues MFA, Alli RCP, Torres BB, Bueno Netto CL, Silva LF: Evaluation of soil Gram-negative bacteria yielding polyhydroxyalkanoate acids from carbohydrates and propionic acid. Appl Microbiol Biotechnol 1996;45:785-791.

Gösseringer R, Kuster E, Galinier A, Deutscherand J, Hillen W: Cooperative and non-cooperative DNA binding modes of catabolite control protein CcpA from Bacillus megaterium result from sensing two different signals. J Mol Biol 1997;266:665-676.

Harding KG, Dennis JS, von Blottnitz H, Harrison STL: Environmental analysis of plastic production processes: comparing petroleum-based polypropylene and polyethylene with biologically-based poly- $\beta$-hydroxybutyric acid using life cycle analysis. J Biotechnol 2007;130:57-66.
Haywood GW, Anderson AJ, Chu L, Dawes EA The role of NADH- and NADHP-linked acetoacetyl-CoA reductase in the ply-3-hydroxybutyrate synthesizing organism Alcaligenes eutrophus. FEMS Microbiol Lett 1988; $137: 41-48$

Henderson RA, Jones CW: Poly-3-hydroxybutyrate production by washed cells of Alcaligenes eutrophus; purification, characterization and potential regulatory role of citrate synthase. Arch Microbiol 1997;168:486-492.

Kim HJ, Roux A, Sonenshein AL: Direct and indirect roles of CcpA in regulation of Bacillus subtilis Krebs cycle genes. Mol Microbiol 2002;45:179-190.

Küster E, Luesink EJ, de Vos WM, Hillen W: Immunological crossreactivity to the catabolite control protein CcpA Bacillus megaterium is found in many gram-positive bacteria. FEMS Microbiol Lett 1996;139:109-115.

Lee IY, Kim MK, Chang HN, Park YH: Regulation of poly-beta-hydroxybutyrate biosynthesis by nicotinamide nucleotide in Alcaligenes eutrophus. FEMS Microbiol Lett 1995; 131:35-39.

Lopes MSL, Rocha RCS, Zanotto SP, Gomez JGC, Silva LF: Screening of bacteria to produce polyhydroxyalkanoates from xylose. World J Microbiol Biotechnol 2009;25:17511756.

Ludwig H, Meinken C, Matin A, Stulke J: Insufficient of the ilv-leu operon encondng enzymes of branched chain amino acid biosynthesis limits growth of a Bacillus subtilis ccpA mutant. J Bacteriol 2002;18:5174-5178.

Lulko AT, Buist G, Kok J, Kuipers OP: Transcriptome analysis of temporal regulation of carbon metabolism by CcpA in Bacillus subtilis reveals additional target genes. J Mol Microbiol Biotechnol 2007;12:82-95

McCool GJ, Cannon MC: Polyhydroxyalkanoate inclusion body-associated proteins and coding region in Bacillus megaterium. J Bacteriol 1999;585-592.

McCool GJ, Cannon MC: PhaC and PhaR are required for polyhydroxyalkanoic acid synthase activity in Bacillus megaterium. J Bacteriol 2001;4235-4243.
Morgenstern B, Frech K, Dress A, Werner T: DIALIGN: Finding local similarities by multiple sequence alignment. Bioinformatics 1998; 14:290-294.

Park JS, Lee YH: Metabolic characteristics of isocitrate dehydrogenase leaky mutant of $\mathrm{Alca}$ ligenes eutrophus and its utilization for polybeta-hydroxybutyrate production. J Ferment Bioeng 1996;81:197-205.

Rocha RCS, Silva LF, Taciro MK, Pradella JGC: Production of poly(3-hydroxybutyrate-co3-hydroxyvalerate) $\mathrm{P}(3 \mathrm{H}-\mathrm{co}-3 \mathrm{HV})$ with a broad range of $3 \mathrm{HV}$ content at high yields by Burkholderia sacchari IPT 189. World J Microbiol Biotechnol 2008;24:427-431.

Rygus T, Hillen W: Catabolite repression of the xyl operon in Bacillus megaterium. J Bacteriol 1992;174:3949-3055.

Sambrook J, Fritsch EF, Maniats T: Molecular Cloning: A Laboratory Manual. Cold Spring Harbor, Cold Spring Harbor Lab Press, 1989.

Silva LF, Taciro MK, Michelin Ramos ME, Carter JM, Pradella JG, Gomez JG: Poly-3-hydroxybutiyrate $(\mathrm{P} 3 \mathrm{HB})$ production by bacteria from xilose, glucose and sugarcane bagasse hydrolysate. Ind Microbiol Biotechnol 2004;31:245-254.

Sonenshein AL: Control of key metabolic intersections in Bacillus subtilis. Nat Rev Microbiol 2007;5:917-927.

Sprehe M, Seidel G, Hillen W: CcpA mutants with differential activities in Bacillus subtilis. J Mol Microbiol Biotechnol 2007;12:96105.

Valappil SP, Rai R, Bucke C, Roy I: Polyhydroxyalkanoate biosynthesis in Bacillus cereus SPV under varied limiting conditions and an insight into the biosynthetic genes involved. J Appl Microbiol 2008;104:1624-1635.

Wacker I, Ludwig H, Reif I, Blencke HM, Detsch C, Stülke J: The regulatory link between carbon and nitrogen metabolism in Bacillus subtilis: regulation of the glt $A B$ operon by the catabolite control protein CcpA. Microbiol 2003;149:3001-3009. 